\title{
MEREFLEKSIKAN CERPEN ROBOHNYA SURAU KAMI KARYA A. A. NAVIS SEBAGAI PENGGUGAH MINAT BACA MAHASISWA PENDIDIKAN BAHASA INDONESIA UNIVERSITAS PELITA HARAPAN
}

\author{
Iko Agustina Boangmanalu \\ iko.boangmanalu@uph.edu \\ Universitas Pelita Harapan
}

\begin{abstract}
Literary work as a social document becomes an effective reflection media. The 'Didaktif' function of literary work indirectly informs readers. Education is given through reflection and it is also connected with personal experiences or society conditions in the reader era. This kind of literature approaching had been existing since the Plato era which was developed by Marxis. Literary work is viewed as a society reflection in a certain era. This approaching is called Mimesis which has long been abandoned by researchers but it needs to be developed to recognice and to appreciate the society's cultural diversity. Robohnya surau kami is a short story containing values of humanity and love end it describes a worship phenomenon which we still find in this era. The sensitivity and the way the writer criticizes society problem becomes the strength of this short story. In additions, characters decision and the conflict seem real though there is a dialogue between human and God after death. The writer shows his high capability in delivering real problems occurring in the community. The story closing makes a surprise. That gives a valuable reading experience and a deep impression so that it attracts students to have an effective reading interest, especially Indonesia Language department students.
\end{abstract}

Key words: reflection, literature, reading interest

\begin{abstract}
ABSTRAK
Karya sastra sebagai dokumen sosial menjadi wadah refleksi yang efektif. Fungsi didaktif karya sastra menyuluh pembaca secara tidak langsung. Pendidikan diberikan lewat permenungan juga mengaitkannya dengan pengalaman pribadi maupun kondisi masyarakat di zaman pembaca. Pendekatan sastra dengan cara demikian sudah ada sejak zaman Plato yang dikembangkan oleh Marxis. Karya sastra dipandang sebagai cerminan masyarakat di era tertentu. Pendekatan ini disebut mimesis, sudah lama ditinggalkan peneliti sastra, tetapi perlu dikembangkan lagi
\end{abstract}


untuk mengenali dan menghargai keragaman budaya masyarakat Indonesia. Robohnya Surau Kami adalah cerpen yang mengandung nilai kemanusiaan, kasih, dan menggambarkan fenomena beribadah yang masih ditemui di zaman ini. Kepekaan dan cara penulis mengkritik persoalan masyarakat yang sensitif menjadi kekuatan cerpen ini. Selain itu, penokohan dan konflik terasa nyata sekalipun ada dialog manusia dengan Tuhan setelah kematian. Penulis menunjukkan kematangannya dalam memaparkan persoalan nyata yang akrab di tengah-tengah masyarakat. Penutup cerita pun menimbulkan keheranan. Hal tersebut memberi pengalaman membaca yang bermakna dan kesan yang mendalam bagi pembaca sehingga dapat menjadi penggugah minat baca yang efektif bagi mahasiswa, khususnya Prodi Pendidikan Bahasa Indonesia.

Kata Kunci: refleksi, karya sastra, minat baca

\section{PENDAHULUAN}

Berbagai upaya telah
dimulai pemerintah untuk
menggalakkan minat baca.
Kebijakan menteri mengharuskan
setiap sekolah membuat program
membaca 15 menit sebelum
pelajaran dimulai. Target satu
desa satu perpustakaan sudah
dicanangkan. Kampanye baca
mulai semarak di media televisi.
Para pegiat literasi bermunculan
dengan nama komunitas masing-
masing. Belum lama ini, presiden
mengeluarkan kebijakan
menggratiskan pengiriman
sumbangan buku ke tempat
$\begin{aligned} & \text { pegiat-pegiat literasi di berbagai } \\ & \text { penjuru Indonesiar agar }\end{aligned}$

masyarakat yang mereka layani memperoleh koleksi buku yang mencukupi. Perpustakaan Nasional yang tertinggi di dunia sudah diresmikan. Duta baca pun tampak jelas geliat usahanya mempromosikan kegiatan baca.

Kampanye baca memang sudah dimulai, namun generasi yang lulus SMA sederajad tahun 2017 dan tahun-tahun sebelumnya belum sempat menikmati dorongan literasi yang baru dirintis tersebut. Rendahnya minat baca yang sejalan dengan geliat menulis masih menjadi momok mahasiswa tahun pertama di Prodi Pendidikan Bahasa Indonesia, UPH. Mereka 
Boangmanalu, Merefleksikan Cerpen Robohnya Surau Kami Karya A. A. Navis sebagai Penggugah Minat Baca Mahasiswa Pendidikan Bahasa Indonesia Universitas Pelita Harapan

berasal dari berbagai latar budaya dengan sebuah kesamaan, yaitu membaca belum menjadi budaya di tengah-tengah masyarakat tempat mereka bertumbuh. Membaca juga bukan aktivitas yang diprioritaskan dalam pembelajaran di sekolah mereka. Hal ini membuat mereka bertemu dengan beragam masalah di bangku kuliah.

Sebagai mahasiswa tentu mereka diperhadapkan dengan aktivitas akademik yang tidak terlepas dari membaca. Mendengarkan pengajaran dosen sangat tidak cukup dan kemandirian belajar memang sangat dituntut. Terlebih mahasiswa Pendidikan Bahasa dan Sastra Indonesia, disamping buku-buku teori, buku-buku sastra menunggu untuk dibaca. Mereka dituntut memiliki wawasan sastra untuk keperluan pengajaran maupun keperluan produksi karya sastra. Tidak hanya itu, sederet alasan mahasiswa harus membaca dapat dengan mudah diutarakan. Fairbairn \& Fairbairn (2006, hh. 35-37) merincikan sedikitnya 25 alasan mahasiswa harus membaca, disarikan menjadi 6 alasan; 1) untuk memperoleh ide atau gagasan saat hendak menulis esai atau makalah; 2) untuk memperdalam pengetahuan terkait bidang ilmu yang digeluti; 3) untuk mendukung argumen atau pemikiran mahasiswa, baik dalam tulisan maupun lisan; 4) untuk memperoleh kesenangan dan latihan berpikir; 5) untuk meningkatkan keterampilan membaca; dan 6) untuk mengembangkan keterampilan menulis. Sederet tuntutan ini mengharuskan mereka membaca maka masalah pun mengikuti kala minat baca masih rendah. Semakin kompleks karena minat baca rendah adalah akar masalah kemampuan menulis.

Latar masalah ini dan kebutuhan yang besar ini mendorong peneliti melakukan berbagai upaya untuk menggugah minat baca mahasiswa Pendidikan Bahasa Indonesia angkatan 2017. Salah 
satunya, menciptakan kegiatan membaca bersama di kelas. Pilihan bacaan menjadi faktor penting untuk usaha ini. Salah satu bacaan yang inspiratif dan reflektif adalah cerpen Robohnya Suaru Kami karya A. A. Navis. Cerpen ini pertama kali dimuat majalah Kisah tahun 1955 kemudian diterbitkan bersama cerpen lain dalam bentuk buku antologi tahun 1956. Cerpen ini telah mendapat penghargaan dan perhatian dari berbagai kalangan masyarakat; praktisi sastra maupun masyarakat biasa, pengajar maupun peneliti. Wahid (2007, hh. 45-46) menilai cerpen Robohnya Surau Kami berhasil menggambarkan fatalisme yang melanda kehidupan beragama. Sindiran terhadap paham masyarakat dalam memaknai ibadah disampaikan lugas, berani, tanpa ragu-ragu, tetapi dikemas rapi juga diselingi bagian yang menggelitik.

Subjek penelitian adalah

31 mahasiswa Pendidikan Bahasa Indonesia Universitas Pelita Harapan angkatan 2017 yang sedang menjalani semester satu. Mereka berasal dari beragam daerah, seperti Papua, Sumba, Sulawesi, Jawa Tengah, Sumatera Utara, Riau dan Bekasi. Hanya 3/31 yang pernah membaca lebih dari 5 novel sampai selesai karena latar pendidikan menengahnya jurusan bahasa. $90 \%$ menyebutkan sangat jarang membaca satu buku sampai selesai. Membaca dilakukan untuk persiapan ujian atau mengerjakan tugas saja. $70 \%$ menyebutkan sulit mengakses bahan bacaan sesuai minat di sekitar sekolah ataupun tempat tinggal mereka dahulu. Selain itu, keluarga, masyarakat, dan warga sekolah juga kurang membudayakan kegiatan membaca. Hal ini membuat rendahnya wawasan literasi mereka. Padahal, pengalaman membaca adalah modal penting untuk menumbuhkembangkan minat baca seseorang. Penelitian ini mencoba mengondisikan kegiatan membaca yang reflektif demi memberi pengalaman membaca yang mengesankan 
Boangmanalu, Merefleksikan Cerpen Robohnya Surau Kami Karya A. A. Navis sebagai Penggugah Minat Baca Mahasiswa Pendidikan Bahasa Indonesia Universitas Pelita Harapan

sehingga meningkatkan minat baca mahasiswa Pendidikan Bahasa Indonesia, Universitas Pelita Harapan.

\section{METODE PENELITIAN}

Penelitian menggunakan metode kualitatif dengan pendekatan mimesis. Pendekatan ini disebut pedekatan paling kuno yang digagas pertama kali oleh Plato kemudian diperbaharui oleh Aristoteles. Plato memandang karya sastra sebagai tiruan dari kehidupan sehari-hari sehingga karya sastra diposisikan lebih rendah daripada kenyataan. Aristoteles beranggapan karya sastra bersifat luhur dan memperdalam jiwa manusia sehingga lebih tinggi kedudukannya. Karya sastra merupakan cerminan kehidupan manusia. Marxis berpendapat karya sastra adalah dokumen sosial. Sekalipun karya sastra diinspirasi oleh kehidupan seharihari, bukan berarti ia tiruan semata (Ratna, 2015, h. 70). Karya sastra lahir dari upaya kreatif penulisnya. Sekalipun karya sastra rekaan penulisnya, bukan berarti ia benar-benar lepas dari kenyataan hidup manusia. Karya sastra bahkan menjadi dokumen sejarah manusia yang paling efektif menjadi wadah belajar. Oleh karena itu, penelitian ini akan memaparkan refleksi pembaca terhadap cerpen Robohnya Surau Kami yang dapat menggugah minat bacanya

\section{HASIL DAN PEMBAHASAN}

Merefleksikan Cerpen Robohnya Surau Kami karya A.A. Navis

Tokoh 'Kakek' diceritakan taat beribadah, seorang garin sekaligus pengasah pisau yang lebih sering menerima ucapan terima kasih daripada sekeping uang atas jasanya. la hidup dari sedekah setiap Jumat, seperempat bagian panen ikan dari kolam dekat surau, dan sedekah Id setahun sekali. Suatu hari, Kakek terusik cerita Ajo Sidi. Dikisahkan percakapan Haji Saleh dan kawan-kawan dengan Tuhan ketika hari penghakiman. 
Haji Saleh mempertanyakan keputusan Tuhan memasukkannya ke neraka. Semasa hidup, ia tekun beribadah, telah lima kali naik haji, rajin berdoa, dan membaca Firman. Oleh ketaatannya beribadah, semestinya ia masuk surga. Tuhan membeberkan kesalahan fatal Haji Saleh. la beribadah karena takut masuk neraka. la beribadah tetapi anak cucunya miskin. Padahal Tuhan telah memberi negeri yang kaya untuk diolah. la beribadah karena untuk itu ia tak perlu berpeluh. Cerita bualan Ajo Sidi benarbenar menggusarkan hati Kakek. Cerpen diakhiri dengan kematian Kakek yang tragis dan Ajo Sidi menyikapinya dengan pergi bekerja.

$\begin{array}{lr}\text { Kemapanan } & \text { A.A.Navis } \\ \text { menyampaikan } & \text { kritiknya } \\ \text { mencengangkan } & \text { pembaca. }\end{array}$

Pembaca ditegur dengan tangan teguh tetapi lembut, dengan suara mengagetkan padahal hanya bisikan. Perwatakan yang disematkan kepada setiap tokoh dapat kita temui di tengah-tengah masyarakat. Latar dan konflik juga sama sekali tidak asing, dengan mudah kita temui dalam kehidupan sehari-hari. Percakapan Haji Saleh dengan Tuhan memang terlihat tidak realis, namun rasional, dapat diterima akal, sama sekali tidak horor, malah dikemas humoris. A.A.Navis mendobrak pemahaman masyarakat yang mensakralkan ibadah, mensekulerkan kerja. Penulis menunjukkan kegoyahan iman Kakek yang kesehariannya dihabiskan di surau dan beribadah. Justru Ajo Sidi sang pembual memperoleh kesempatan memperbaiki dirinya. Berikut ini akan dipaparkan refleksi subjek penelitian setelah membaca cerpen Robohnya Surau Kami dalam dua topik; 1) ibadah dan kerja serta 2) ibadah dan iman.

\section{Ibadah dan Kerja}

Pertanyaan pertama Tuhan kepada Haji Saleh bukan 'siapa' tetapi 'apa pekerjaan Haji Saleh di dunia' (kata "pekerjaan" pada konteks ini bermakna luas). Tidak 
Boangmanalu, Merefleksikan Cerpen Robohnya Surau Kami Karya A. A. Navis sebagai Penggugah Minat Baca Mahasiswa Pendidikan Bahasa Indonesia Universitas Pelita Harapan

sesuai dengan ekspektasi Haji Saleh yang membanggakan kesiapaannya yang bergelar Haji. Tuhan lebih memperhitungkan kerja apa yang telah diperbuat manusia selama di bumi. Penulis menyoroti hal 'kerja' sejak di awal cerpen dengan memperkenalkan tokoh Kakek lewat apa yang ia kerjakan; sebagai garin dan sebagai pengasah pisau. Hal ini dapat pula ditemukan dari dialog Tuhan dengan Haji Saleh. Dalam dialog tersebut ada delapan kali Tuhan menanyakan kerja apa yang telah diperbuat Haji Saleh selama di bumi. Haji Saleh berbangga memaparkan ibadahnya. Setiap hari setiap malam menyembah Tuhan, menyebut-nyebut nama Tuhan, berdoa, dan membaca kitab suci. Akan tetapi, Tuhan tidak mengindahkan.

Tidak jauh berbeda dengan Haji Saleh, Kakek digambarkan sebagai tokoh religius. Tidak selalu ada orang yang membutuhkan jasanya mengasah pisau. Kakek pun hidup dari sedekah umat di saban Jumat dan Hari Raya. Sekali enam bulan hasil panen ikan dari kolam dekat surau yang ia pelihara dibagikan juga seperempatnya kepada Kakek. Selebihnya, ia habiskan waktu untuk sembahyang, berdoa, dan membaca Kitab Suci. Kakek memilih tidak membangun keluarga agar fokus pada ibadah dan meningkatkan ketakwaannya kepada Tuhan.

A.A. Navis ingin mengkritik pendikotomian ibadah dan kerja melalui tokoh Kakek dan Haji Saleh. Keduanya berpandangan bahwa sembahyang, berdoa, menyebut-nyebut nama Tuhan, dan membaca kitab-Nya saban hari lebih mulia daripada bertani, berdagang, menjadi pelayan di rumah makan, atau pekerjaan lainnya. Bahkan tokoh Kakek tidak membangun keluarga sebab dapat saja mengganggu kefokusan beribadah. Pada konteks ini, ibadah dimaknai sebatas kegiatan yang berkaitan dengan sembahyang dan berdoa. Tuhan dikenali sebagai pribadi yang gila puja dan puji sehingga 
ibadah pada makna sempit itulah yang menyenangkan dan berkenan kepada Tuhan.

Pendikotomian ibadah dan kerja tidak hanya ada dalam cerita ini. A.A. Navis mengangkatnya karena pemahaman demikian sangat mudah ditemukan dalam kehidupan masyarakat di bumi, tidak hanya Indonesia. Fenomena ini juga tidak jauh dari lingkungan sekitar kita atau tanpa sadar juga kita lakukan. Sekalipun karya ini diterbitkan tahun 1955, masalah pemisahan ibadah dan kerja masih kontekstual di era ini jika tidak ingin kita sebut semakin parah. Sembahyang ke rumah ibadah dipandang lebih mulia daripada bekerja dengan jujur tanpa korupsi. Berdoa lebih suci daripada bekerja dengan disiplin. Membaca kitab suci lebih berkenan bagi Tuhan daripada belajar ilmu-ilmu bumi atau sosial. Membayar nazar tetaplah luhur sekalipun uangnya hasil curian atau perasan.

Cikal bakal pemahaman yang melihat ibadah (kontemplasi) lebih tinggi nilainya daripada kerja dapat dirunut ke pemikiran Aristoles dalam Whelchel (2015, hh. 62-63) “...bahwa pekerjaan tangan atau kerja untuk upah adalah hal yang melemahkan semangat dan rendah." Oleh karena itu, "...tidak bekerja adalah peruntungan baik, sebab memungkinkan orang untuk berpartisipasi dalam kehidupan kontemplasi." (Whelchel, 2015, h. 63). Pemikiran ini juga yang mempengaruhi pandangan Roma dan Yunani terhadap kerja. Gereja abad pertengahan terpampang pengaruhnya juga sehingga menilai bahwa bekerja memenuhi panggilan Tuhan adalah melayani penuh waktu dalam kegiatan gerejawi bahkan diharuskan hidup selibat. mereka melihat ibadah dan melayani Tuhan adalah keluar dari dunia menuju hidup tapa. Membangun keluarga dan memiliki anak dipandang baik tetapi dapat menghalangi kemaksimalan melayani. 
Boangmanalu, Merefleksikan Cerpen Robohnya Surau Kami Karya A. A. Navis sebagai Penggugah Minat Baca Mahasiswa Pendidikan Bahasa Indonesia Universitas Pelita Harapan

Kepiawaian A.A. Navis menyampaikan kritiknya terhadap dikotomi ibadah dan kerja menggugah pembaca untuk merenung, mengevaluasi pemahaman sendiri, mencari kebenaran. Apakah ibadah tidak lebih mulia dan penting daripada kerja di mata Tuhan? Apa sebenarnya mandat utama manusia di bumi, menyembah Tuhan atau bekerja? Apakah bekerja bagian dari ibadah? Salah satu subjek penelitian menuliskan hasil refleksinya:

"saya belajar bahwa
memuliakan Tuhan
tidak hanya dapat
dilakukan rat saat
beribadah saja namun
juga saat kita
melakukan kehendak-
Nya dalam hal in
bekerja keras (Al)"

Subjek penelitian menyadari bahwa kerja yang dilakukan untuk memuliakan Tuhan adalah ibadah. Kesadaran ini perlu dimiliki setiap manusia teisme sebab tanpa kesadaran demikian akan kita temukan ketidakkonsistenan antara praktik ibadah dan praktik hidup seharihari. Umat berbaris teratur di rumah ibadah tetapi semrawutan ketika di jalan raya, membuat macet, memperkeruh suasana. Remaja-remaja lekas ketika gotong royong membersihkan rumah ibadah, namun berat hati ketika dimintai orang tuanya membantu pekerjaan rumah. Rumah ibadah penuh dengan umat sepenuh sel-sel tahanan, seramai pengedar narkoba, operasi tangkap tangan oleh KPK atau penegak hukum lain. Jumlah dana persembahan ke rumahrumah ibadah sebanyak pajak yang ditunggak, sebanyak uang negara yang dikorupsikan.

Pemisahan kerja dan ibadah bahkan berdampak lebih jauh lagi. Hal ini menunjukkan sikap kita yang tidak menyadari bahwa tidak ada barang sesentipun bagian hidup ini yang bukan kepunyaan Tuhan. Ketika di rumah ibadah atau di tempat kerja, ketika sembahyang atau di depan komputer, ketika berdoa atau mengajar di kelas, semuanya milik Pencipta dan untuk Pencipta.

\section{Ibadah dan Iman}


Sudah lama aku tak marah-marah lagi. Takut aku kalau imanku rusak karenanya, ibadatku rusak karenanya. Sudah begitu lama aku berbuat baik, beribadat, bertawakal kepada Tuhan. Sudah begitu lama aku menyerahkan diri kepada-Nya. Dan Tuhan akan mengasihi orang yang sabar dan tawakal.

(Robohnya Surau Kami, A.A. Navis)

Semakin rajin beribadah, semakin kuat pula iman seseorang, itulah pemahaman kebanyakan masyarakat. Marah tidak mencerminkan keimanan yang kuat sehingga seseorang yang marah, sekalipun marah terhadap tindakan yang melanggar hukum dipandang kurang baik oleh masyarakat. Kakek dan Haji Saleh adalah tokoh yang digambarkan rajin beribadah. Asumsi logisnya, kedua tokoh ini tentu memiliki iman yang kuat. Iman yang kokoh walau diterpa badai pencobaan.
Iman yang mengenal betul apa yang dipercayainya.

A.A.Navis menabrak paradigma masyarakat yang menilai semakin giat ibadah, semakin kokoh iman seseorang. Haji Saleh dengan percaya diri memperkenalkan gelarnya di hadapan Tuhan, percaya bahwa itulah hal berharga yang Tuhan indahkan. Haji Saleh jumawa menilai Tuhan salah paham sehingga meminta penjelasan akan nasibnya yang dibuang ke neraka. Kedua penggambaran ini dipakai A.A.Navis untuk menunjukkan bahwa kegemaran seseorang beribadah belum tentu menambah pengenalannya akan yang ia sembah. Tokoh Kakek juga tidak kalah ibadahnya, namun goyah hanya oleh bualan Ajo Sidi. Bukan Ajo Sidi yang membunuh Kakek dengan ceritanya. Kakeklah yang kehilangan pegangan, apa yang ia percayai selama hidup remuk oleh pemahaman baru dari cerita Ajo Sidi (Taib, 2007,h. 6). Hal ini menjadi poin refleksi subjek 
Boangmanalu, Merefleksikan Cerpen Robohnya Surau Kami Karya A. A. Navis sebagai Penggugah Minat Baca Mahasiswa Pendidikan Bahasa Indonesia Universitas Pelita Harapan

penelitian, seperti pada kutipan berikut

"tokoh Kakek kurang percaya diri akan imannya sehingga Kakek akhirnya bunuh diri (AC)"

Iman dan pengenalan kedua tokoh terhadap yang dipercaya tidak berbanding lurus dengan kuantitas ibadahnya di dunia. Hal ini menjadi paradoksal bagi pemahaman masyarakat pada umumnya. Seseorang yang giat dan banyak ibadahnya selalu dinilai sebagai orang yang tebal imannya. Sosok demikian akan menjauh dari hal-hal yang dapat mengganggu kukuh kepercayaannya. la cenderung beraktivitas di zona yang nyaman, yang paling sedikit kemungkinan baginya untuk melakukan pelanggaran. Iman yang berada di kolam susu dan madu. Iman yang makan dan istirahatnya seimbang. Sekali lagi, dengan berani Ali Akbar Navis menegur kondisi tersebut. Iman yang kokoh lahir dari proses pemurnian. Kekuatan akar tidak divalidasi oleh angin sepoi-sepoi, tetapi badai dan hujan deras.

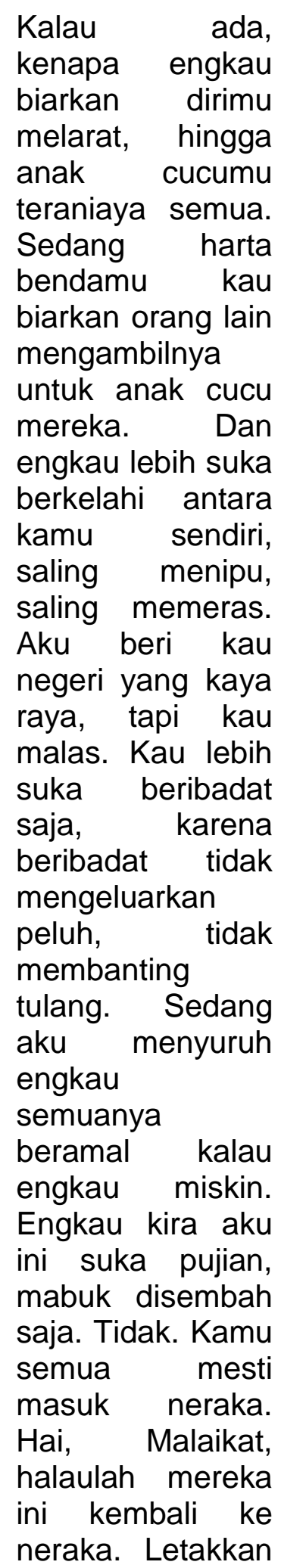


di keraknya!

(Robohnya Surau

Kami, A.A. Navis)

Haji saleh dan temantemannya bergeming ketika menghadap Tuhan. Mereka tak dapat menyangkal, persis seperti jawaban Tuhan yang dikutip itulah perbuatan mereka selama hidup di bumi. Candu beribadah, mensakralkan segala atribut dan aktivitas keagamaan serta mensubordinasi hal nonkeagamaan. Miskin dalam kutipan tersebut bukan sebatas tidak punya harta yang melimpah, tetapi juga miskin ilmu, miskin keahlian sehingga tak mampu mengelola kekayaan alam yang Tuhan limpahkan. Anak cucu sendiri pun tidak memperoleh tuntunan untuk mengembangkan kemampuan dan keterampilan mereka. Mereka membaca Kitab Suci, tetapi tidak meresapinya sehingga tidak dapat memahami bahwa mengasihi keluarga, mengasihi sesama juga ibadah dan berkenan di hadapan Tuhan.

Sikap demikian masih kita temui di tengah-tengah masyarakat saat ini.
Penggalangan dana membangun rumah ibadah, dana untuk membela saudara seiman, atau lain-lain yang dilabeli agama akan mendapat banyak perhatian masyarakat. Namun, penyumbang-penyumbang dana tersebut tiap hari dapat menutup mata dari penderitaan tetangganya, warga sekompleks rumahnya, sedesanya, di kantornya. Pelanggaran seseorang terkait atribut agama lebih hina daripada korupsi. Setiap hal berlabel keagaaman memperoleh kasih dan perhatian yang lebih. Sekalipun berbuat baik dalam konteks di luar keagamaan, hal demikian dipandang lebih rendah daripada perbuatan baik dalam konteks keagamaan. Kasih yang dipraktikkan adalah kasih yang sangat terbatas.

\section{KESIMPULAN}

Karya sastra tidak dapat dipandang sebagai ciptaan dari yang tidak ada, milik pengarang seutuhnya. Karya sastra selalu lahir dari pergulatan manusia 
Boangmanalu, Merefleksikan Cerpen Robohnya Surau Kami Karya A. A. Navis sebagai Penggugah Minat Baca Mahasiswa Pendidikan Bahasa Indonesia Universitas Pelita Harapan

terhadap kehidupan nyata, terhadap problem di masyarakat. Sastra dan sosiologi memiliki objek yang sama, yaitu masyarakat. Perbedaannya, sastra menggali kehidupan sosial lewat penghayatan sedangkan sosiologi mengkajinya dengan telaah objektif dan ilmiah (Damono dalam Wiyatmi, 2013, h. 7). Dalam cerpen Robohnya Surau Kami, A.A.Navis menggali kehidupan

masyarakat, khususnya aktivitas ibadah kemudian memaparkan hasilnya kepada pembaca. Terlihat nyata apa yang dipaparkan merupakan pergulatan A.A.Navis terhadap fenomena yang ada di kehidupan nyata, bukan rekaan semata. Penulis menggunakan masyarakat imajiner (tokoh-tokoh dalam karya sastra) untuk menunjuk masyarakat faktual (masyarakat dalam kehidupan nyata) (Ratna, 2010:279).

Kekuatan cerita ini meninggalkan pengalaman yang berkesan bagi pembaca. Selain memantik berefleksi juga memantik keingintahuan pembaca terhadap bacaan sastra lainnya. Robohnya Surau Kami mengandung pesan sosial yang sangat dalam dan memberi pengalaman membaca yang berkesan bagi pembacanya. Paradigma masyarakat yang memisahkan ibadah dan kerja, mengkultuskan ibadah dan tidak menghadirkan Pencipta dalam kerja, benar-benar disoroti A.A.Navis sehingga pembaca dibawa berefleksi. Kekuatan pesan yang disampaikan, kemapanan penulis dan pengalaman membaca yang diberikan A.A. Navis memantik rasa ingin tahu untuk membaca karya-karya yang lain.

\section{ACUAN PUSTAKA}

Fairbairn Gavin J. \& Susan A. Fairbairn. (2001). Budaya Baca di Universitas. Terj. Frans Kowa Jakarta: Indeks.

Navis, Ali Akbar. (2007). Robohnya Surau Kami. Jakarta: Gramedia Pustaka Utama.

Ratna, Nyoman Kutha. (2010). Sastra dan Cultural Studies: Representasi Fiksi dan Fakta. Yogyakarta: Pustaka Pelajar. 
JDP Volume 11, Nomor 2, Juli 2018: 139-152

Ratna, Nyoman Kutha. (2015).

Penelitian Sastra: Teori, Metode, dan Praktik. Yogyakarta: Pustaka Pelajar.

Taib, Mohamed Imran Mohamed. (2007). Menilai Kembali Peran Agama di dalam Masyarakat.

Dipresentasikan pada Sesi Wacana dan Pembacaan bersama siswa jurusan agama, 22 Agustus $2007 \mathrm{di}$ Al-Mawardi Muis, Toa Payoh.

Wahid, Abdurrahman. (2007). Menggerakkan Tradisi: Esai-esai Pesantren. Yogyakarta: LKiS.

Wiyatmi. (2013). Sosiologi Sastra. Yogyakarta: Kanwa Publisher.

Whelchel, Hugh. (2015). Mengubah Dunia Melalui Kerja. Terj. Paul S. Hidayat. Jakarta: Waskita Publishing. 